\title{
Spectrophotometric Estimation of Ganciclovir in Pharmaceutical Formulations using Alizarin Sulfonic Acid Sodium Salt Reagent
}

\author{
Usra I.S. AL-Neaimy \\ Department of Physiology / Biochemistry and Medicine \\ College of Veterinary Medicine \\ University of Mosul
}

Received

07 / 06 / 2011
Accepted

02 / $11 / 2011$

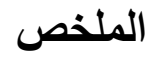

تم تطوير طريقة طيفية بسيطة وسريعة لتقدير المركب الدوائي غانسيكلوفير بهيئته النقية وفي مستحضراته الصيدلانية. اعتمدت الطريقة على تفاعل تكوين مزدوج ايوني للمركب الدوائي

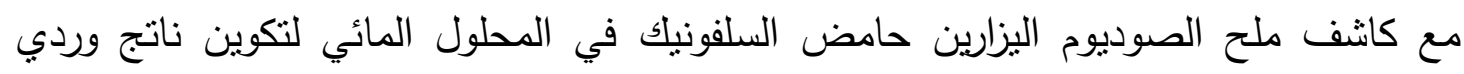

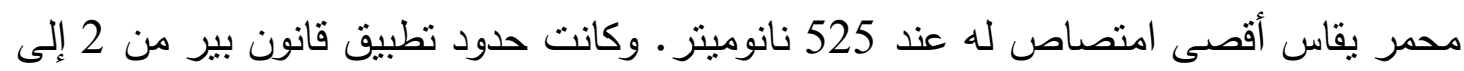

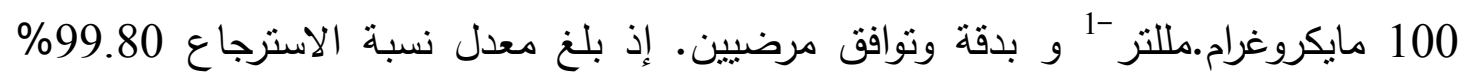

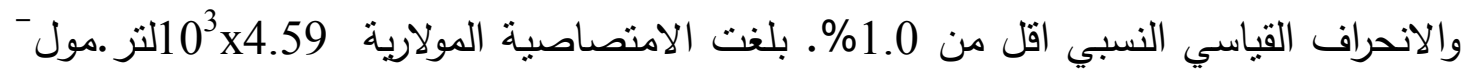

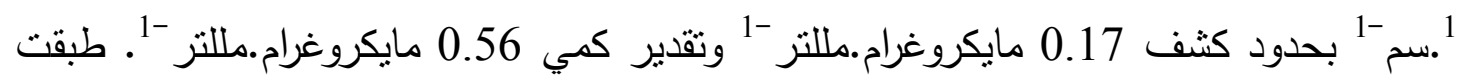

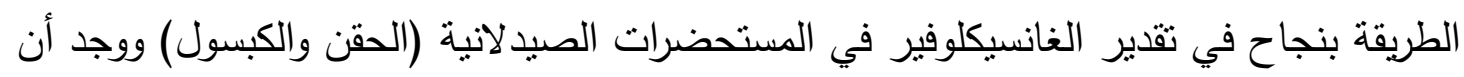
نتائج الطريقة متفقة مع محتوى المستحضر الصيدلاني وكذلك مع طريقة الإضافة القياسية.
\end{abstract}

\section{ABSTRACT}

A simple and rapid spectrophotometric method has been developed for the determination of antiviral drug (Ganciclovir) in a bulk sample and in its dosage forms. The method depends on the ion-pair formation reaction of the drug with alizarin sulfonic acid sodium salt reagent in aqueous solution to form a pinkish - red color product showing maximum absorbance at $525 \mathrm{~nm}$. Beers law is obeyed in the concentration range $2-$ $100 \mu \mathrm{g} \cdot \mathrm{ml}^{-1}$ with average recovery (accuracy) $99.80 \%$ and precision (RSD) is less than $1.0 \%$. The molar absorptivity is $4.59 \times 10^{3} 1 . \mathrm{mol}^{-1} \cdot \mathrm{cm}^{-1}$ with LOD $0.17 \mu \mathrm{g} \cdot \mathrm{ml}^{-1}$ and LOQ $0.56 \mu \mathrm{g} \cdot \mathrm{ml}^{-1}$. The method is successfully employed for the determination of Ganciclovir in pharmaceutical formulations as an injection and capsule and the results 
are compatible with both certified values of pharmaceutical formulations and the standard addition method.

Keywords: ganciclovir; spectrophotometric; alizarin sulfonic acid sodium salt.

\section{Introduction}

Ganciclovir (GCV) or 9-(1,3-dihydroxy-2-propoxymethyl) guanine, Fig.(1) is an acyclic nucleoside analogue of 2-deoxyguanosine that inhibits replication of herpes viruses. It is used for the prevention of cytomegalovirus (CMV) disease in organ or bone marrow transplant recipients and in HIV-infected individuals who are at risk of developing CMV disease. GCV is a white crystalline powder with a molecular formula of $\mathrm{C}_{9} \mathrm{H}_{13} \mathrm{~N}_{5} \mathrm{O}_{4}$ and a molecular weight $255.23 \mathrm{~g} / \mathrm{mol}^{(1,2)}$.<smiles>Nc1nc(=O)c2ncn(COC(O)CO)c2[nH]1</smiles>

Fig. 1: The chemical structure of Ganciclovir

Few analytical methods have been reported for the estimation of GCV in biological fluids or pharmaceutical formulations. High performance liquid chromatographic (HPLC) analysis of GCV in plasma samples using a mobile phase $0.02 \mathrm{M} \mathrm{KH}_{2} \mathrm{PO}_{4}$ with $\mathrm{UV}$ detection at 254 nm was investigated ${ }^{(3)}$.

Also capillary electrophoresis method was used for GCV determination in human plasma with UV detection at $254 \mathrm{~nm}^{(4)}$.

The determination of GCV in human serum and pharmaceutical dosage forms was investigated using differential pulse and square wave voltammetry ${ }^{(5)}$.

Spectrophotometric methods have been developed for the determination of GCV in bulk drug and its pharmaceutical formulations such as the reaction of GCV with p-dimethylamino cinnamaldehyde ${ }^{(6)}$, a charge transfer reaction of GCV (n- electron donor) with several $\sigma$ and $\pi$ acceptors ${ }^{(7)}$ and first order derivative spectroscopy ${ }^{(8)}$. GCV also was estimated at $253 \mathrm{~nm}$ in $0.1 \mathrm{~N} \mathrm{HCl}$ and at $266 \mathrm{~nm}$ in $0.1 \mathrm{~N} \mathrm{NaOH}^{(9)}$.

Alizarin sulfonic acid sodium salt has been frequently utilized as an analytical reagent in pharmaceutical analysis. It has been used for the colorimetric determination of ceterizine hydrochloride at $440 \mathrm{~nm}^{(10)}$, clotrimazole and ketoconazole at $425 \mathrm{~nm}^{(11)}$, piroxicam and tenoxicam ${ }^{(12)}$, nefopam, mebevrine and phenylpropanol amine hydrochloride ${ }^{(13)}$.

Spectrophotometric analysis is considered more convenient alternative technique to determine GCV because of its simplicity and its high sensitivity. Therefore the objective of this work was to develop a 
simple spectrophotometric method to determine the drug in the pure form and its pharmaceutical formulations.

\section{Apparatus}

\section{Experimental}

A shimadzu UV - 1650 a digital double beam spectrophotometer with 1 - cm glass cells used for all spectral and absorbance measurements.

\section{Reagents}

GCV from (European Directorate for the Quality of Medecines \& HealthCare), alizarin sulfonic acid sodium salt hydrate $\left(\mathrm{C}_{14} \mathrm{H}_{7} \mathrm{NaO}_{7} \mathrm{~S}\right.$. $\mathrm{H}_{2} \mathrm{O}$ ) analytical reagent grade from Merck (Germany) were used.

\section{Standard GCV (1000 $\left.\mu \mathrm{g} . \mathrm{ml}^{-1}\right)$ solution}

A stock solution of GCV was prepared by dissolving $0.1000 \mathrm{~g}$ in sufficient quantity of distilled water and the volume made up to $100 \mathrm{ml}$ with distilled water. Further dilution was made with distilled water to get the concentration of $100 \mu \mathrm{g} \cdot \mathrm{ml}^{-1}$.

\section{Alizarin sulfonic acid sodium salt hydrate $\left(1 \times 10^{-3} \mathrm{M}\right)$ solution}

This solution was prepared by dissolving $0.0171 \mathrm{~g}$ alizarin sulfonic acid sodium salt hydrate in distilled water and then the volume was made up to a $50 \mathrm{ml}$ with distilled water in a $50 \mathrm{ml}$ volumetric flask.

\section{Procedure for calibration}

To a series of $10 \mathrm{ml}$ volumetric flasks, transfer increasing volumes of GCV working standard solution to cover the range $(2-100) \mu \mathrm{g} \cdot \mathrm{ml}^{-1}$ in final dilution. Add $2 \mathrm{ml}$ of $1.00 \times 10^{-3}$ mol.L $\mathrm{L}^{-1}$ alizarin sulfonic acid sodium salt hydrate. Dilute the solution to the mark with distilled water. The absorbance was measured at $525 \mathrm{~nm}$ after 10 minutes at room temperature against the blank solution which was prepared in a similar way but without the addition of GCV.

\section{Assay procedure for dosage forms}

\section{1- Injection:}

A vial of cymevene (IV) from Roche contains $500 \mathrm{mg}$ ganciclovir. The content of two vials were mixed and an amount of the powder equivalent to $500 \mathrm{mg}$ of the component was weighed and dissolved in distilled water and filtered then completed to the mark in a $100 \mathrm{ml}$ volumetric flask, from the above solution $20 \mathrm{ml}$ was pipette out into a 100 $\mathrm{ml}$ volumetric flask and the volume was made up to the mark with distilled water. Further dilution was made with distilled water to get the concentration of $100 \mu \mathrm{g} \cdot \mathrm{ml}^{-1}$. The solution was proceeded as described under procedure for calibration.

\section{2- Capsule:}


An accurately weighed quantity of the mixed contents of 10 capsules (Lovir from Oubari Pharma - Aleppo - Syria), an amount equivalent to $250 \mathrm{mg}$ of the drug was dissolved in sufficient quantity of distilled water and filtered then the volume was made up to $100 \mathrm{ml}$ with distilled water. From the above solution $40 \mathrm{ml}$ was pipette out into a 100 $\mathrm{ml}$ volumetric flask and the volume was made up to the mark with distilled water. Further dilution was made with distilled water to get the concentration of $100 \mu \mathrm{g} \cdot \mathrm{ml}^{-1}$. The solution was proceeded as described under procedure for calibration.

\section{Results and Discussion}

The absorption spectrum of GCV was measured in the range 400$800 \mathrm{~nm}$ against the blank solution. GCV was reacted with alizarin sulfonic acid sodium salt hydrate to produce an pinkish- red colored ion pair complex with maximum absorption at $525 \mathrm{~nm}$ in contrast to the reagent blank which shows maximum absorption at $420 \mathrm{~nm}$ Fig.(2).

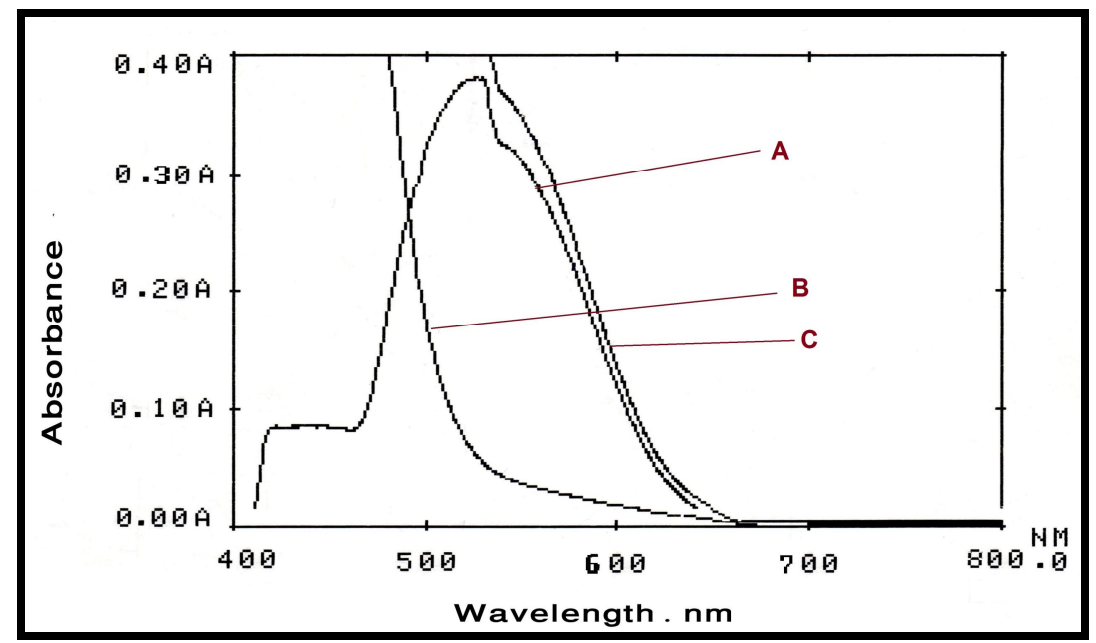

Fig. 2: Absorption spectra of $20 \mu \mathrm{g}$. $\mathrm{ml}^{-1}$ of GCV treated according to the procedure and measured against blank (A), blank against distilled water (B), GCV treated according to the procedure and measured against distilled water $(C)$.

\section{Optimization of conditions}

For the subsequent experiments, $200 \mu \mathrm{g}$ of GCV is taken and the final volumes are $10 \mathrm{ml}$.

\section{Effect of pH:}

Since alizarin sulfonic acid sodium salt hydrate behaves as an acid - base indicator so neither acid nor base were used in the reaction medium $^{(14)}$.

\section{Effect of the reagent concentration:}

The effect of the reagent was investigated by taking various amounts (0.5-3) $\mathrm{ml}$ of the reagent which was added to an aliquot of solution containing $200 \mu \mathrm{g} .10 \mathrm{ml}^{-1}$ of GCV and following the general 
procedure. The better absorption was observed with the addition of $2 \mathrm{ml}$ of the reagent (Table 1).

Table 1: Effect of alizarin sulfonic acid sodium salt concentration

\begin{tabular}{|c|c|c|c|c|c|c|}
\hline $\begin{array}{c}\text { ml of alizarin sulfonic acid } \\
\text { sodium salt hydrate } \\
\left(1 \times 10^{-3} \mathrm{M}\right)\end{array}$ & 0.5 & 1 & 1.5 & 2.0 & 2.5 & 3.0 \\
\hline Absorbance & 0.099 & 0.158 & 0.331 & 0.385 & 0.298 & 0.178 \\
\hline
\end{tabular}

\section{Effect of time and temperature:}

The reaction time was determined by following the color intensity at room temperature and in thermostatically controlled water - bath adjusted at 50 and $60 \mathrm{C}^{\circ}$. The experiment showed that the colored dye developed immediately and the absorbance remained stable for at least 6 hours. All conditions studied were optimized at room temperature $(25 \pm 1$ $\mathrm{C}^{\circ}$ ) which give the best color intensity (Table 2).

Table 2: Effect of temperature and reaction time

\begin{tabular}{|c|c|c|c|c|c|c|c|c|}
\hline \multirow{3}{*}{$\begin{array}{c}\text { Temp } \\
\left(C^{\circ}\right)\end{array}$} & \multicolumn{8}{|c|}{ Absorbance } \\
\hline & \multicolumn{8}{|c|}{ Time (min) } \\
\hline & 5 & 10 & 20 & 40 & 60 & $2 \mathrm{~h}$ & $4 h$ & $6 h$ \\
\hline R.T & 0.385 & 0.384 & 0.385 & 0.385 & 0.385 & 0.385 & 0.385 & 0.385 \\
\hline 50 & 0.382 & 0.381 & $\mathbf{0 . 3 7 7}$ & 0.372 & 0.368 & 0.350 & 0.332 & 0.319 \\
\hline 60 & 0.379 & 0.378 & 0.369 & 0.367 & 0.361 & 0.348 & 0.323 & 0.309 \\
\hline
\end{tabular}

\section{Effect of surfactant:}

The effect of different types of surfactants was studied, but none of them improve the absorption intensity therefore they were excluded from this study (Table 3)

Table 3: Effect of surfactant

\begin{tabular}{|l|c|c|c|c|}
\hline \multirow{2}{*}{ Surfactant } & \multicolumn{4}{|c|}{ Absorbance/ml surfactant } \\
\cline { 2 - 6 } & 0.5 & 1 & 2 & 3 \\
\hline Cetyltrimethylammonium bromide (0.1\%) & 0.380 & 0.378 & 0.377 & 0.375 \\
\hline Sodium dodecyl sulphate (0.1\%) & 0.381 & 0.379 & 0.380 & 0.378 \\
\hline Triton x-100 (1\%) & 0.382 & 0.380 & 0.378 & 0.377 \\
\hline Without surfactant & \multicolumn{5}{|c|}{0.385} \\
\hline
\end{tabular}

\section{Analytical data}

Beer's law plot was obeyed in the concentration range (2-100) $\mu \mathrm{g} . \mathrm{ml}^{-1}$ for GCV (Fig. 3) with a correlation coefficient, molar 
absorptivity, regression equation were given in Table 4 . In order to determine the accuracy and precision of the proposed method the recoveries (R \%) and relative standard deviation (RSD \%) for three different concentrations of drug were also calculated and recorded in Table 5.

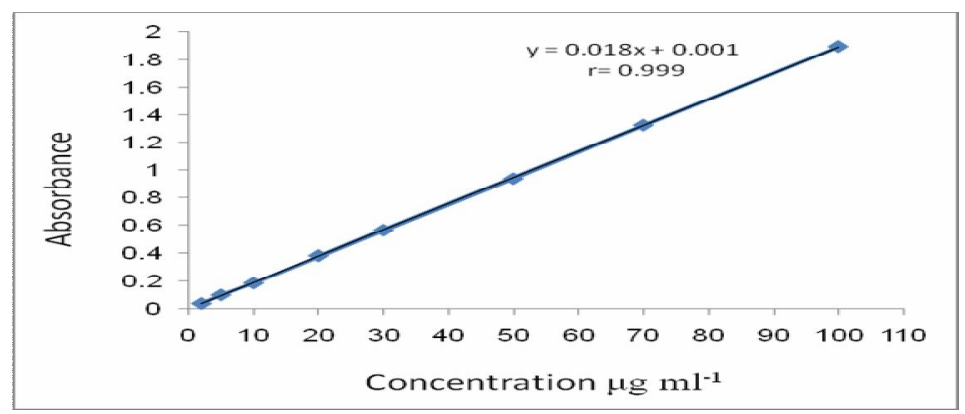

Fig. 3: Calibration curve of Ganciclovir

Table 4: Quantitative parameters for the complexation of GCV with alizarin sulfonic acid sodium salt hydrate.

\begin{tabular}{|c|c|}
\hline Parameter & Values \\
\hline$\lambda_{\max }(\mathrm{nm})$ & 525 \\
\hline Beer's law limit $\left(\mu \mathrm{g} . \mathrm{ml}^{-1}\right)$ & $2-100$ \\
\hline Molar absorptivity $\left(1 . \mathrm{mol}^{-1} \cdot \mathrm{cm}^{-1}\right)$ & $4.59 \times 10^{3}$ \\
\hline \multicolumn{2}{|l|}{ Regression equation(Y)* } \\
\hline Slope (a) & 0.018 \\
\hline Intercept(b) & 0.001 \\
\hline Correlation coefficient (r) & 0.999 \\
\hline LOD $\left(\mu \mathrm{g} \cdot \mathrm{ml}^{-1}\right)$ & 0.17 \\
\hline LOQ $\left(\mu \mathrm{g} \cdot \mathrm{ml}^{-1}\right)$ & 0.56 \\
\hline
\end{tabular}

* $\mathrm{Y}=\mathrm{ax}+\mathrm{b}$, where $\mathrm{x}$ is the concentration of GCV in $\mu \mathrm{g} \cdot \mathrm{ml}^{-1}$ and $\mathrm{Y}$ is the absorbance

Table 5: Accuracy and precision of the method.

\begin{tabular}{|c|c|c|c|}
\hline $\begin{array}{c}\text { Taken } \\
\left(\mu \mathrm{g} \cdot \mathrm{ml}^{-1}\right)\end{array}$ & $\begin{array}{c}\text { Found } \\
\left(\mu \mathrm{g} . \mathrm{ml}^{-1}\right)\end{array}$ & Recovery $^{*}(\%)$ & RSD $^{*}(\%)$ \\
\hline 20 & 19.94 & 99.70 & 0.50 \\
\hline 50 & 49.91 & 99.82 & 0.15 \\
\hline 70 & 69.92 & 99.88 & 0.11 \\
\hline
\end{tabular}

* Average of six determinations

\section{Interferences}

In order to assess the possible analytical application of this spectrophotometric method to drug quality control, the interfering effect of some common excipients at various levels on the determination of GCV was examined and the results were given in (Table 6). 
Table 6: Effect of interferences

\begin{tabular}{|l|c|c|c|c|}
\hline \multirow{2}{*}{ Excipient } & \multicolumn{4}{|c|}{ Recovery \% $\boldsymbol{\mu}$ of excipient added } \\
\cline { 2 - 5 } & 500 & 1000 & 2000 & 3000 \\
\hline Starch & 101.51 & 102.87 & 103.65 & 104.91 \\
\hline Magnesium stearate & 98.70 & 103.93 & 104.87 & 103.23 \\
\hline Croscarmellose sodium & 101.12 & 99.23 & 98.54 & 102.56 \\
\hline Microcrystalline cellulose & 98.56 & 99.76 & 101.21 & 103.32 \\
\hline
\end{tabular}

From the results in Table (6), it can be observed that none of the excipients can introduce significant interference.

\section{Nature of product and reaction mechanism}

The stiochiometry of the reaction between the drug and the reagent was investigated using continuous variation method ${ }^{(15)}$, the results obtained show that 1:1 drug to reagent was formed Fig. (4).

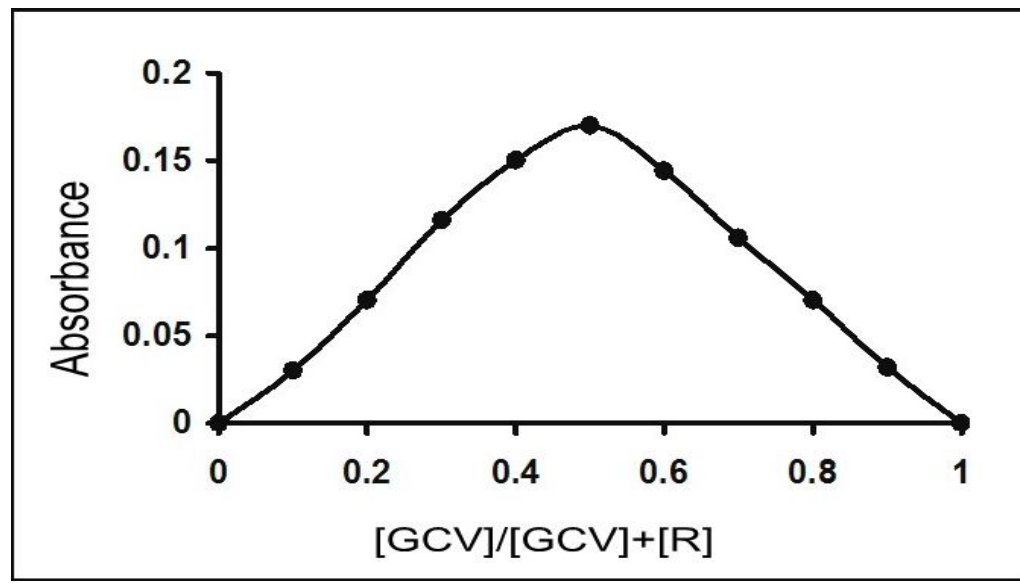

Fig. 4: Continuous variation plot of GCV with alizarin sulfonic acid sodium salt $(R)$ reagent

Therefore, the formation of the product may be occur as follows ${ }^{(16-18) .}$<smiles>O=C1c2cc(O)c(O)c(O)c2C(=O)c2c(O)ccc(O)c21</smiles><smiles>Nc1nc(=O)c2ncn(COC(=O)O)c2[nH]1</smiles><smiles></smiles><smiles>Nc1nc(=O)c2ncn(COOCO)c2[nH]1</smiles>

The stability constant of the ion-pair complex in aqueous solution, under the conditions of experimental procedure was calculated, and found to be $1.78 \times 10^{4} 1 . \mathrm{mol}^{-1}$.

\section{Application}

The proposed method was applied to the determination of GCV in pharmaceutical formulations. Good recovery was obtained and the results compared with the standard addition method (Fig. 5, Fig.6 and Table 7). 


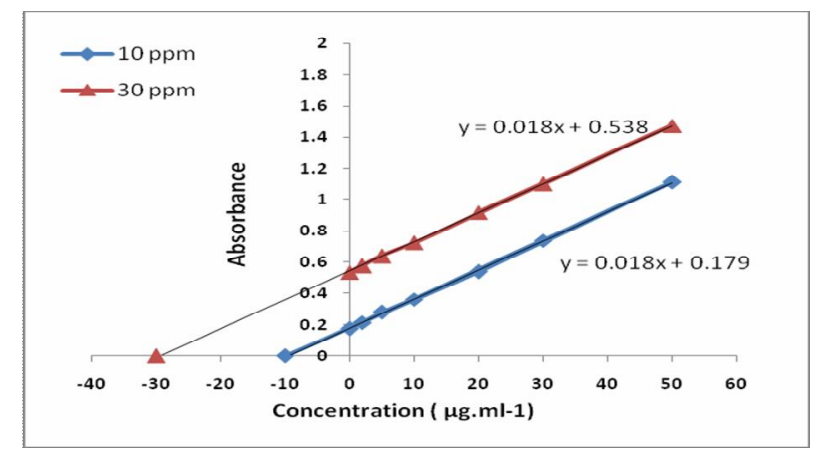

Fig.5: Standard addition graph of GCV in pharmaceutical formulation (injection)

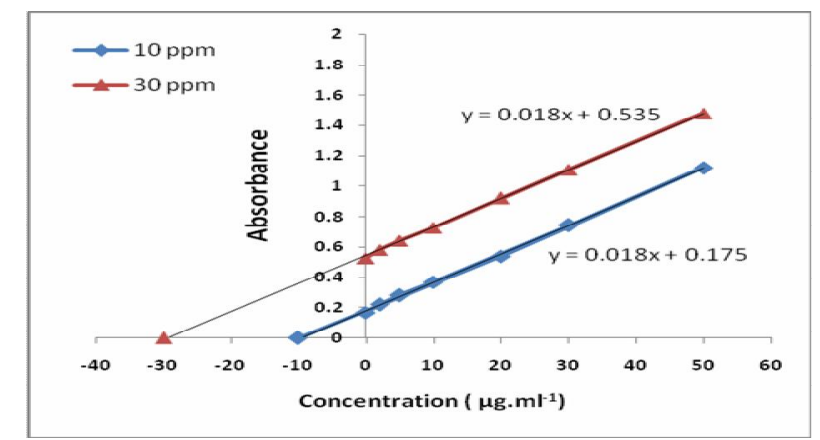

Fig.6: Standard addition graph of GCV in pharmaceutical formulation (capsule)

Table 7: Assay and recovery of GCV in pharmaceutical dosage forms.

\begin{tabular}{|c|c|c|c|c|c|c|}
\hline \multirow{2}{*}{$\begin{array}{l}\text { Pharmaceutical } \\
\text { dosage form }\end{array}$} & \multirow{2}{*}{$\begin{array}{l}\text { Certified } \\
\text { value }\end{array}$} & \multirow{2}{*}{$\begin{array}{c}\text { Amount of } \\
\text { GCV added } \\
\left(\mu \mathrm{g} \cdot \mathrm{ml}^{-1}\right)\end{array}$} & \multicolumn{2}{|c|}{$\begin{array}{c}\text { Drug content found } \\
(\mathrm{mg})\end{array}$} & \multicolumn{2}{|c|}{ Recovery*(\%) } \\
\hline & & & $\begin{array}{l}\text { Present } \\
\text { method }\end{array}$ & $\begin{array}{l}\text { Standard } \\
\text { addition } \\
\text { method }\end{array}$ & $\begin{array}{l}\text { Present } \\
\text { method }\end{array}$ & $\begin{array}{l}\text { Standard } \\
\text { addition } \\
\text { method }\end{array}$ \\
\hline \multirow{2}{*}{$\begin{array}{l}\text { Cymevene } \\
\text { (Injection) }\end{array}$} & \multirow{2}{*}{$500 \mathrm{mg} /$ vial } & 10 & 498.10 & 494.45 & 99.62 & 98.89 \\
\hline & & 30 & 498.55 & 497.20 & 99.71 & 99.44 \\
\hline \multirow{2}{*}{$\begin{array}{c}\text { Lovir } \\
\text { (Capsule) }\end{array}$} & \multirow{2}{*}{$250 \mathrm{mg} /$ capsule } & 10 & 248.00 & 241.70 & 99.20 & 96.68 \\
\hline & & 30 & 247.05 & 247.22 & 98.82 & 98.88 \\
\hline
\end{tabular}

*Average of three determinations

\section{Comparison of methods}

The results obtained by application of the present method and literature method $^{(6)}$ to the determination of $\mathrm{GCV}$ in pharmaceutical preparations were given in (Table 8).

Table 8: Comparison of methods

\begin{tabular}{|c|c|c|}
\hline Analytical parameter & Present method & Literature method $^{(6)}$ \\
\hline$\lambda_{\max }(\mathrm{nm})$ & 525 & 524 \\
\hline Temp $\left({ }^{\circ} \mathrm{C}\right)$ & R.T & 40 \\
\hline Linear range $\left(\mu \mathrm{g} \cdot \mathrm{ml}^{-1}\right)$ & $2-100$ & 10-50 \\
\hline Molar absorptivity $\left(1 . \mathrm{mol}^{-1} \cdot \mathrm{cm}^{-1}\right)$ & $4.59 \times 10^{3}$ & $1.175 \times 10^{3}$ \\
\hline Limit of Detection (LOD/ $\left./ \mu \mathrm{g} . \mathrm{ml}^{-1}\right)$ & 0.17 & 0.425 \\
\hline
\end{tabular}




\begin{tabular}{|l|c|c|} 
Limit of Quantification $\left(\mathrm{LOQ} / \mu \mathrm{\mu g} . \mathrm{ml}^{-1}\right)$ & 0.56 & 4.60 \\
\hline Type of reaction & Ion -pair complex & Condensation \\
\hline Composition of the dye & $1: 1$ & $1: 1$ \\
\hline Analytical application & Injection and capsules & Capsules \\
\hline
\end{tabular}

It is evident from Table 8 that the present method is more sensitive than the most recently -published method on GCV determination.

\section{Conclusion}

Alizarin sulfonic acid sodium salt hydrate is a suitable reagent for the determination of $\mathrm{GCV}$ in pure form or in its dosage forms. The suggested method is simple and does not require neither buffer solution nor solvent extraction.

\section{REFERENCES}

1) Sweetman S. C., "Martindale: The Complete Drug Reference", $34^{\text {th }}$ Edn, Pharmaceutical Press, London, pp. 635-637,(2005).

2) Katzung B. G., "Basic and Clinical Pharmacology". $9^{\text {th }}$ Edn., Mc Graw Hill, Singapore,pp.806-808, (2007).

3) Boulieu R., Bleyzac N. and Ferry S., J.Chromatogr., 567, 481-484, (1991).

4) Saleh S., Hempel G., Electrophoresis,27, 2439-2443,(2006).

5) Uslu B., Dogan B.and Özkan S.A., Anal. Chim. Acta, 537, 307-313, (2005).

6) Sarsambi P. S., Gowrisankar D., Sonawane A. and Faheem A., Int. J. ChemTech Res., 2, 282-285, (2010).

7) Gouda A. A., Talanta, 80, 151-157, (2009).

8) Sarsambi P. S., Sonawane A., Malipatil S.M., Hiremath B. and Faheem A., Int. J. PharmTech. Res., 2, 1264-1268,(2010).

9) Sarsambi P. S., Sonawane A., Malipatil S.M. and Raju S.A., J. Ind. Council Chem., 27,202-204,(2010).

10) Basavaiah K., Srilatha and Swamy J.M., Talanta, 50,887892,(1999).

11) Farhadi K. and Maleki R., J. Pharm. Biomed. Anal., 30, 1023-1033, (2002).

12) Amin A.S., J. Pharm.Biomed.Anal.,29, 729-736, (2002).

13) Shama S.A. and Amin A.S., Spectrochim. Acta Part A: Molecular and Biomol.Spec.,60, 1769-1774, (2004).

14) Barbosa J., Bosch E. and Carrera R., Talanta, 32,1077-1081, (1985).

15) Hargis L.G., "Analytical Chemistry, Principels and Techniques", Prentice - Hall Inc, New Jersey, pp. 424 - 427, (1988).

16) Kamel M.S., Barsoum B.N. and Sayed R., J.Appl. Sci., 5,880-886, (2009).

17) Nesalin J.A.J., Babu C.J.G., Kumar G.V. and Mani T.T., J.Chem., 6, 780-784, (2009).

18) Al-Delymi A.M.S., "Development of spectrophotometric methods in organic and drug analysis", Ph.D. Thesis, University of Mosul, (2006). 